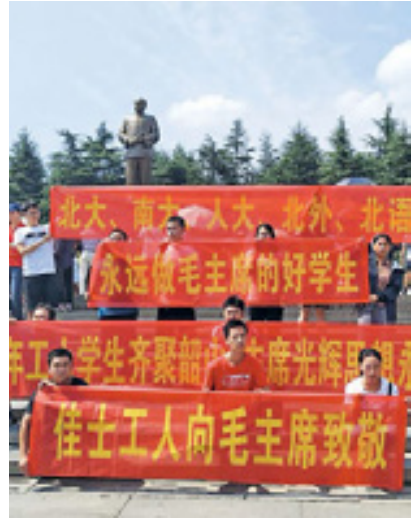

Jasic workers holding a banner that reads: "Jasic workers pay tribute to Chairman Mao."
The Jasic case is unusual in that it was supported openly by a group of some 50 self-proclaimed Maoists and Marxist university students, along with a small group of older citizens.

\section{The Jasic Mobilisation A High Tide for the Chinese Labour Movement?}

\author{
Au Loong Yu
}

In July this year, 89 workers at the Shenzhen Jasic Technology Co. Ltd demanded the right to set up a workplace union. In the past decade there has been an explosion of strikes in Shenzhen, and this dispute is one of the many where workers have demanded better working conditions, owed wages, unpaid social insurance, and severance pay. Yet, the Jasic case is unusual in that it was supported openly by a group of some 50 self-proclaimed Maoists and Marxist university students, along with a small group of older citizens. Coming from different parts of China, they organised themselves into a 'Jasic Worker Support Group' and descended on Jasic to stand in solidarity with the workers who were battling the police.

At the height of the Jasic campaign, these old and young Maoist supporters held up photos of Chairman Mao and a banner reading 'To Be Good Students of Chairman Mao Forever'. They created a website-which has now been removed from the Internet-called 'Vanguard of the Era' (shidai xianfeng) calling for more support for their cause, 'for the sake of the working class's awakening, for the sake of Chairman Mao!' (Wu 2018). As the images that accompany this article show, they uploaded photographs of themselves on social media posing in Maoistlike revolutionary heroic postures, disciplined and determined to fight for their cause. One of them posted an article entitled 'Where Has Jinggangshan Gone? On the Jasic Struggle and the Future of Revolutionary Revival' (Luo 2018). Referring to the mountain where Mao first established his guerrilla base in 1927 and to Mao's revolutionary strategy of 'encircling cities from the rural areas' (nongcun baowei chengshi), it proclaimed 'Jinggangshan is here right now at Jasic and in all industrial areas.'

Although Jasic supporters might not really be advocating for an armed uprising, they do believe that the time is ripe for leftists in China to escalate worker struggle from economic to political. The very moment the Maoists got involved, the

\footnotetext{
(1) Part of this essay first appeared in Chinese in the Mingpao Daily, 30 August 2018. A more lengthy discussion on the issue by the same author will appear in the January 2019 issue of New Politics (newpol.org). All information reported here comes from the Internet or personal contacts.
} 
incident quickly escalated from a workplace trade union organising drive to a political struggle against local officials. The heroic campaign was quickly and violently suppressed. Four workers were arrested, charged with disturbing the peace, and are now awaiting trial. At the time of writing, 28 supporters remain either under house arrest or have been forcibly disappeared (HRIC 2018). As for the students, after they went back to their universities, they were interrogated, disciplined, investigated, threatened, and in some cases expelled. In the past three months, more than 20 students have been fiercely manhandled-some were beaten up, some were attacked and kidnapped by thugs right on campus, and some have simply disappeared. How are we to assess this unprecedented incident in which students and workers struggle together across institutions, across provinces, across generations, and across class boundaries?

Professor Pun Ngai at the University of Hong Kong has argued that the Jasic mobilisation is a movement of 'unity between workers and students' and is of 'historical significance' (Pun 2018). Indeed, the case is significant because it was the first time in the past few decades that students have emerged in such a high profile and organised manner to support a worker protest. This stands in sharp contrast to what happened in Tiananmen Square in 1989, when intellectuals and students cordoned themselves off from the workers at the very beginning of the protests. After the democratic movement of the late $1980 \mathrm{~s}$ failed, intellectuals soon split into two main groups: Liberals (ziyoupai) and the New Left (xinzuopai). Both of these groups subscribed to the false dichotomy of 'state versus market', while remaining indifferent to the plight of the working masses.

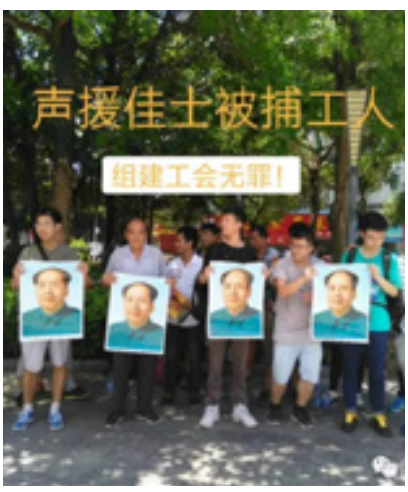

Jasic workers holding Mao's picture.
At best, only a handful of the New Left intellectuals adopted a rhetoric of 'fairness' in their writings by counterposing the liberal slogan of 'prioritising efficiency' for future reform with 'prioritising justice' instead. As for the students, they simply retreated to their study. It was not until the 2009 Guangzhou sanitation workers strike that workers began to receive some support from students, who mostly participated as individuals, rather than as a coordinated group. Thus, the fact that in the Jasic incident, more than 50 students put themselves at risk by acting in solidarity with the workers was indeed a new development.

Nevertheless, Professor Pun goes on to make two other points that I have reservations about. Firstly, she commends the incident as having a second historical significance in that for 'the first time the workers consciously organised a trade union.' 
The factory has just over a thousand workers.

So the fact that 89

workers signed on

to request a labour

union be established-

with 20 remaining

in the struggle after

the crackdown-is

significant, particularly

considering the

difficulty of labour

organising in this type

of context.

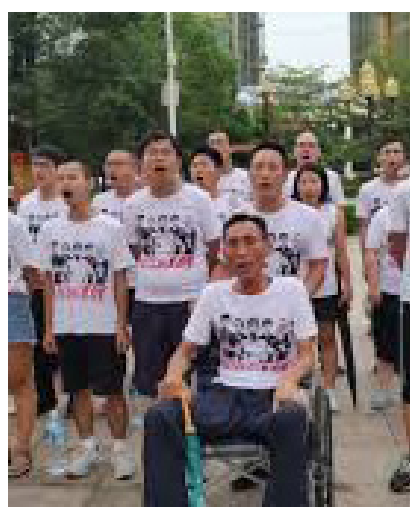

Jasic workers young and old.
The reality is that there have been numerous cases of workers going on strike to demand the re-electing or establishment of workplace unions. For example, as early as 2004-05, workers at the Shenzhen Japanese company Uniden went on strike five times in one year. They finally succeeded in setting up a union but it was quickly suppressed. Other examples were the Ole Wolff case in Yantai in 2006, the Yantian Container strike of 2007, and last but not least, the Nanhai Honda strike of 2010.

Secondly, she remarks that 'the actions of the Jasic workers also show that Chinese workers have already transformed from purely economic subjects into political subjects with class consciousness.' True, the protest was initially quite promising. The factory has just over a thousand workers. So the fact that 89 workers signed on to request that a labour union be establishedwith 20 remaining in the struggle after the crackdown-is significant, particularly considering the difficulty of labour organising in this type of context (Zhang 2018). However, is it possible to conclude that the average Chinese worker has become a 'political subject with class consciousness' based on the actions of a less than 100 people in a single workplace?

Now that the suppression of students has captured the attention of the international media, it is worth looking at the origins of these Maoist student groups in a bit more detail. The re-emergence of Maoist ideology among the younger generation can be traced to the turn of the century. At that time, some older Maoists in North China began to resist the privatisation of state-owned enterprises (SOEs) from behind the scenes. They also invited rural migrant activists and students to their classes and trainings. In 2005, they founded the 'China Labour Research Web' (zhongguo gongren yanjiu wang), later renamed 'Red China' (hongse zhongguo), which was closed down by the authorities in 2010. At that time, these Maoists prioritised SOE workers over rural migrant workers as they regarded the former as more 'revolutionary' and the latter as lacking class consciousness. They mostly focussed their activities around the SOE workers in the North, and if there were Maoist NGOs working in the South they maintained a very low profile. The current rise of a new generation of young Maoist students engaging so deeply in the Jasic struggle indicates the Maoists are turning their attention to rural migrant workers in the South. That in the Jasic case they have decided to adopt a tactic of high-profile confrontational resistance, was evidence of their determination and commitment given the highly repressive situation. 
Earlier this decade, 'Red China'-along with 'Utopia' (wuyouzhixiang), a Maoist website founded in 2003 by the well known Maoist/Nationalists Fan Jinggang and Han Deqianghad placed their hopes in Bo Xilai to lead a left turn in the Party. For instance, Minqi Li, an academic based in the United States and a theoretician of 'Red China', placed great expectations in Bo as 'the last significant faction that was in opposition to neoliberal capitalism', and argued that 'by purging Bo Xilai from the Party, the Chinese Communist Party (CCP) leadership may have foregone their last and best opportunity to resolve China's rapidly escalating economic and social contradictions in a relatively peaceful manner' (Li 2016, 183 and 38).

The fall of Bo in 2012 shattered these hopes, and since then the two labels 'Left Maoists' (maozuo) and 'Right Maoists' (maoyou) have become common currency in online debates. This means that the Maoists have definitely split into at least two camps: Right Maoists continue to advocate for the support of the Party, as summed up in the slogan, 'Defend the Party and Save the State' (baodang jiuguo), while Left Maoists, such as 'Red China', have become more radical in criticising the Party, having finally come to recognise that a qualitative transformation to capitalism has taken place in China. Since the rise of Xi Jinping onwards, they have become more explicit in advocating resistance from below while continuing to try to win over leading Party cadres through the invocation of the 'socialist' principles enshrined in the Constitution or in Mao's work.

Although the Maoists have accumulated a lot of experience in the North in supporting the rights of SOE workers, their experiences cannot be applied to the workers in the private enterprises of the South without being substantially adapted. When the SOEs underwent privatisation in the late 1990s to early 2000s, the workers sometimes directly confronted corrupt local officials who were responsible for the theft of

Although the Maoists have accumulated a lot of experience in the North in supporting the rights of SOE workers, their experiences cannot be applied to the workers in the private enterprises of the South without being substantially adapted. public property. They deployed the revolutionary ethos of the CCP to legitimise their political resistance. This was natural and was even sometimes useful. But in the private companies of the South it is different. The conflict is chiefly one between employees and employers. Moreover, the revolutionary ethos of the CCP is less likely to resonate with migrant workers, and so if actions escalate into political resistance the workers are less likely to be motivated. Therefore, in the Jasic case, as in many other cases, when the local government cracked down on workers the struggle turned political. But when looking at the possibility to escalate this type of struggle one must also ask the question: are workers fully prepared for a political confrontation? Experience already tells us that in this specific case they were not. 
The Chinese authorities in reality do not have any interest in 'socialist' principles, nor in Mao or Maoism. While Xi Jinping continues to demand that the people learn from Marxism, Leninism, and Mao's Thought; paradoxically, the Party-state continues to crack down on any independent and collective efforts to seriously study the classic texts of the left, and ramps up its attacks even more when these efforts carry an aspiration to sympathise with the working people. Repressing the resurgence of Maoism among the people is not new. Back in 2004 the Zhengzhou police arrested and charged local Maoists who tried to assemble to pay tribute to Mao. The Partystate's crackdown on the Jasic workers and students today is just another incident reminding us that the CCP has long since betrayed its own founding doctrine and is hostile to anyone who wants to interpret Maoism differently from the officially sanctioned line.

There is much for us to learn from the Jasic case. It should be the catalyst for us to begin a long overdue public debate on the situation and strategy of China's labour movement in the midst of a crisis-ridden society. Whereas previously labour constituted a silent majority which remained basically absent from the debate between Liberals and the New Left, the Jasic case reminds us that the situation is changing, that more workers now want their voices to be heard, and that a debate on all these issues is increasingly urgent. 